\title{
BYSTANDER CPR IN TWO PITTSBURGH COMMUNITIES
}

\author{
Kathleen Winter, Ph D, R N. Carl Ross, M.S.N., R.N.
}

\section{UNIVERSITY ADDRESS 600 Forbes Avenue, School of Nursing UNIVERSITY TELEPHONE (412) 396-6541/5229}

\section{ABSTRACT}

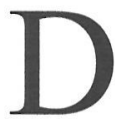
espite recent reduction in mortality, coronary heart disease (CHD) continues to be the leading cause of death in the United States. Most of these deaths occur suddenly and out-ofhospital. There is strong evidence that cardiopulmonary resuscitation (CPR) provided by a bystander at the scene of an arrest doubles the chances of survival for a victim.

It is clear that the death rate for coronary heart disease is higher among blacks than among whites, yet black individuals are less likely to receive bystander CPR. Research evidence as to exactly why this problem exists is not clear (Cowie, et al., 1993). This study proposes to refine and test a questionnaire which will identify the number of individuals trained to do CPR, their willingness to perform CPR, and potential barriers to performance. This will then be administered to a random sampling of adults residing in two Pittsburgh communities where demographics indicate a high proportion of black residents.

Based on the data, the investigators will seek external funding to develop a culturally competent provide CPR education and remove barriers willingness to perform CPR for members of intervention that will lmpactlng on the two communities.

\section{A. OBJECTIVES:}

The overall purpose of this study is to provide the investigators with baseline data upon which to develop an intervention that will increase bystander CPR participation by minority individuals. The long term specific aim of the study is to increase the survival rate of African American cardiac arrest victims.

The objectives of this study are: (1) to refine and pilottest an instrument that will identify potential CPR bystanders (individuals who have recei- ved training in Cardiopulmonary Resuscitation); and (2) to determine the extent to which the adult population residing in two select Pittsburgh communities, with a high density of African American residents, are prepared and willing to provide bystander CPR.

The research questions are:

- What are the demographic characteristics of the sample?

- What proportion of the target population is prepared and willing to provide bystander CPR?

- What barriers are identified which may limit CPR participation?

\section{B. SIGNIFICANCE:}

Research on cardiovascular disease in minorities is highly fundable by the National Institutes of Health (NIH), because it is one of the competitive areas identified for nursing research. However, in order to bè competitive for funding it is imperative to obtain baseline data through pilot and preliminary studies. This study, which fllls gaps in the literature on CPR among minority populations, would contribute to decreased mortality among African American citizens who are at great risk for sudden death due to cardiac etiology.

Cardiovascular disease accounts for nearly 1 million deaths in the United States annually, and approximately 500,000 of these are sudden deaths as a result of coronary heart disease (CHD)

(Guidelines for Cardiopulmonary Resuscitation and Emergency Care, JAMA 1992). Death rates for CHD are higher among men than women and among blacks than whites (Healthy People 2000, 1991).

Over half of the deaths from heart attacks occur during the first few hours after the onset of symptoms and prior to reaching the hospital (Jones and Mitchell, 1993). Immediate action at the first evidence of a heart attack is critical in saving heart tissue by reducing the incidence of ischemic-induced 
ventricular fibrillation thereby reducing morbidity and mortality from CHD. (Healthy People 2000).

The American Heart Association (AHA) has identified significant links in a chain of survival that must be initiated for victims of sudden cardiac death. Early initiation of cardiopulmonary resuscitation to the victim of sudden cardiac death is one of the most critical links in the survival rate of the victim. However, black victims of out-of-hospital cardiac arrest receive bystander CPR less frequently than white victims, therefore targeted training programs may be needed to improve rates among high-risk groups (Brookoff et al., 1994). Cowie et al. (1993) reported a markdly poorer initial resuscitation rate among Black and White victims ( $17.1 \%$ vs. $40.7 \%)$ (p. 955$)$.

Despite determined efforts, the national impact of citizen CPR training has been limited by a variety of factors. It is important to determine the number of individuals who have been trained in CPR and to further investigate barriers to the provision of CPR on selected victims, especially in minority communlties.

\section{HISTORICAL PERSPECTIVE:}

1) Introduction - Coronary heart disease continues to be the number one killer in the United States. This has sparked many investigations about bystander-initiated cardiopulmonary resuscitation.

The faculty of Duquesne University School of Nursing were contacted by leaders of the Hill District and East Liberty, and asked to conduct CPR classes for several groups. These classes were provided and a research team from the School of Nursing was subsequently established and awarded seed funding by the school to begin preliminary investigation of the community need for CPR. Funding is now being sought to expand this project.

2) Literature Review - The review of the literature has revealed a need to educate individuals in the community in CPR. The purpose of training individuals in CPR/BLS (Basic Life Support) is to increase the survival rate and decrease the complication rate following sudden cardiac death. Successful treatment of sudden cardiac death starts in the community with prevention and education. If the community is provided with this education, individuals can potentially identify appropriate situations requiring early intervention.

Almost all of the cited literature and investigations credit early bystander CPR as being maximally effective when started at the time of patient collapse. In most clinical studies, bystander CPR has been reported to have a significant positive effect on survival (Cummins 1993).

Cummins et al. (1985) in a study ( $\mathrm{n}=1297)$ of witnessed outof-the hospital cardiac arrest caused by heart disease, demonstrated an improved survival rate when CPR was initiated by bystanders within four minutes. Guzy et al. (1983) concluded that bystander CPR, initiated prior to the arrival of paramedics, produced a fourfold improvement in survival. The data supports the effectiveness of bystander CPR survival following cardiac arrest.

Weaver, Fahrenbruch, \& Johnson (1993) studied the link between early CPR with early defibrillation. In a logistic regression analysis of survival in 244 witnessed arrest, the authors found delay with initiation of CPR and delay with early defibrillation predicted mortality following sudden cardiac death. In witnessed cases, survival rates decreased almost three percent for each minute of delay before initiation of CPR and continued to fall four percent for each minute after initiation of CPR until delivery of first defibrillatory shock. When CPR was begun within three minutes of collapse and the countershock was delivered shortly thereafter, 23 of 33 such patients (70\%) survived.

Two other studies which strongly support the benefit of early bystander CPR and that early bystander-initiated CPR leads to better survival were conducted by Cummins and Pepe. The study conducted by Cummins (1993) revealed that bystander-initiated CPR produced a $27 \%$ survival rate, whereas when CPR was delayed until emergency medical services (EMS) arrived the survival rate was only $13 \%$. The second study conducted by Pepe (1990) revealed a 40\% versus $19 \%$ survival rate difference in bystander and EMSinitiated CPR.

According to Brookoff et al. (1994), out-ofhospital cardiac arrest accounts for more than 250,000 deaths in the United States every year. There is strong evidence that bystander CPR dou- 
bles survival. The investigators, however, found that black adults in Tennessee who experienced out-of-hospital cardiac arrest either at home or in a public place were only half as likely $(9.8 \%$ vs.21.4\%) to receive bystander CPR than white residents of that state. This information was based on 1068 consecutive cases of nontraumatic out-ofhospital cardiac arrest. Memphis, Tennessee is a city of equal numbers of blacks and whites. The reasons for the demonstrated racial differences in the likelihood of bystander CPR were unclear.

Cowie et al. (1993) reported that minority populations are less knowledgeable in regard to CPR. This study also revealed that black victims of out-of-hospital cardiac arrest may be less likely to have CPR Initiated by a bystander (p.959).

Hanks (1990) carried out a study which revealed that bystanders are more willing to help if they perceive themselves as being competent and are of the same psychological and social background as the victim.

In summary, the review of the literature clearly identifies two key elements related to survival rates of victims suffering from sudden cardiac death: (1) bystander-initiated CPR improves the survival rate of victims suffering from sudden cardiac death; and (2) there is a discrepancy in survival rates between white and black adults who suffer from cardiac arrest.

The review of the literature and Duquesne University School of Nursing's community involvement in underserved communities has set the groundwork for this project. The investigators visualize the study conducted in two phases: (1) pilot-test a questionnaire which will identify what proportion of the population in two black communities is prepared as potential CPR bystanders (individuals trained in CPR), who these bystanders are and their willingness to perform CPR; and (2) conduct a mailed survey of adult residents in the two targeted communities.

3) Investigator's Expertise - Duquesne University School of Nursing's commitment to underserved areas flows from the mission of the University. The School of Nùrsing's faculty and students have been actively involved with the Hill District and East Liberty for the past three years. Examples of this involvement include nurse-mana- ged wellness clinics, health fairs, and CPR classes. The princlpal investigator and her students have conducted community assessments of both of these communities. The assessment data were obtained from key informants of the community. The assessments focused on population, level of education, religion, availability of health care in emergencies, and morbidity and mortality. When these informants were asked about CPR training they emphasized the need for such education.

The investigators have been in contact with experts in the provision of Pittsburgh's Emergency Medical Services, particularly at the Center for Emergency Medicine. According to Chief Robert Kennedy, City of Pittsburgh Emergency Medical Services, only $35 \%$ of CPR episodes involved citizen bystander participation. No data are available which would distinguish between CPR response at the neighborhood level. Based on the literature (Cowie, Fahrenbruch, Cobb, \& Hallstrom, 1993), Pittsburgh's underserved communities would expect to report less knowledge of CPR and black victims would be less likely to have CPR initiated by a bystander.

The principal investigator's (Dr. Kathleen Winter) expertise is in community health and community health education. She holds a Doctorate in community health education and has supervised numerous graduate and undergraduate students in the conduct of community assessments and the implementation of health interventions with aggregates. As a community health nurse and long standing member of the American Public Health Association, Dr. Winter is committed to reducing morbidity and mortality in at risk groups.

The co-investigator's (Carl Ross) expertise is in critical care nursing and CPR instruction. $\mathrm{He}$ holds a Master of Science degree in Nursing Education with a specialization in critical care. Mr. Ross has worked for nine years in critical care and maintains a clinical practice in critical care. He is a Basic Cardiac Life Support (BCLS) instructor and holds certification in Advanced Cardiac Life Support (ACLS). For the past seven years he has been active in teaching CPR in hospitals, in the community, and internationally in Nicaragua. He has worked in a variety of critical care settings, 
hospitals, home care, and community based rehabilitation. In January, 1995, Mr. Ross was a member of a critical care team who taught critical care to a group of nurses and physicians in Nicaragua. He chairs the School of Nursing's International Nursing Committee. Mr. Ross is committed to transcultural nursing both locally and internationally, and especially to increasing the survival rate of those individuals who are at high risk for sudden cardiac death.

\section{METHODOLOGY:}

1) Research Design - A survey design is the appropriate design for this phase of the study. A mailed questionnaire developed by the investigators (attached), based on a review of relevant literature, will serve as the data collection instrument.

2) Phase one - Instrument Development

1. The questionnaire will be reviewed by a panel of content experts in the field of cardiovascular medicine and nursing for content validity.

2. A pilot study will be done with selected lay representatives of an African-American community for consideration of wording, readability, and cultural bias. This pilot testing will be done with approximately 10 adult individuals residing in a community with characteristics similar to those of the communities to be surveyed. 3. The questionnaire will be revised based upon the input of both of the above groups.

3) Phase two - Mailed survey

1. IRB approval will be obtained. The study should qualify as exempt.

2. Questionnaires will be mailed to the adult population of two sections of Pittsburgh (the Hill District and East Liberty). According to the 1990 census the total adult population in the Hill District is 10,513 and in East Liberty it is 6,543.

Ideally, the investigators would like to survey the entire adult population of both communities; however, due to accessibility and financial constraints, a systematic random sampling design will be used. From a mailing list of adult residents every third name will be chosen as a subject and mailed a questionnaire.

2. Expected return will be $33 \%$ or greater and if the expected return is not met, a second mailing will be done. Other measures that will be used to increase the probability of a $33 \%$ return rate: (a) pamphlets/posters publicizing the project in key areas of the community, such as churches and community centers; and (b) billboards publicizing the project at strategic locations within the community.

3. Data will be analyzed according to the research questions. Because the study is exploratory specific hypotheses are not constructed a priori. Data analysis will use descriptive statistics (frequencies) to delineate: (a) demographic characteristics of the sample; (b) experience with CPR; (c) willingness to learn CPR; and (d) perceived barriers. Inferential statistics ( $\mathrm{t}$-test) will be used to ascertain differences in willingness to learn CPR and perceived barriers according to selected demographic characteristics.

4) Time/Schedule of Project Activities Once IRB approval is granted and funding is approved, project activities will proceed according to the following time line. Due to the full-time faculty responsibilities of the investigators, a 16 month budget for completion of the study is requested.

\section{Months 1 - 5}

(5 months) Refine and Summary pilot-test created questionnaire Final revision

\section{Months 6 - 10}

(5 months) Publicity for project Data collection Second mailing if needed

Months 11 - 13

(3 months) Interim Database created

Months 14 - 15

(2 months) Summarization of results Draft manuscript

\section{Month 16}

(1 month) Submit final-report Begin educational intervention

\section{E. RESULTS:}

Through this study, the investigators will identify the most important characteristics of the target population in the two communities in order to serve as a basis for the development of a culturally competent intervention. The intervention will include CPR education, address barriers impacting on willingness to perform CPR, and decrease the 
morbidity and mortality in the two target communities.

\section{F. EVALUATION:}

The evaluation of the study will be based upon the accomplishment of the two objectives. An acceptable community participation rate for return of mailed surveys has been set at $33 \%$ by the investigators. Data from the study will be monitored by the interdisciplinary team which originally helped to conceptualize the study.

This interdisciplinary team of nurses and physicians which conceptualized the study will participate both in the evaluation of the results and preparation of the National Institute of Health (NIH) proposal. The advisory committee from the target communities will assist in evaluating the results for cultural competence.

\section{G. FUTURE PLANS:}

1) Fundina Possibilities - Based on the results of this project the investigators plan to pursue external funding to:

(1) initiate an educational component in CPR, which is culturally sensitive and utilizes interventions that will address barriers identified in the community survey; and (2) extend the use of the investigator developed and tested bystander CPR questionnaire throughout the metropolitan Pittsburgh area.

It is further hoped that based upon these data a culturally competent intervention may be developed as a model for other health professionals dedicated to improved health outcomes for minority populations.

2) Publication/Presentation Possibilities - As a result of this study, it is expected that the investigators will develop a number of manuscripts and gain opportunities for presentations. These opportunities will emphasize both the testing of the questionnaire as well as the study results.

The refinement of the questionnaire may stimulate the creation of a database for use by researchers in other cities for the provision of benchmark data.

\section{H. BUDGET NARRATIVE}

- The following descriptions are intended to serve as justification of how funds will be used:

\section{EOUIPMENT}

Statistical Software Package

A software package that will be used for data entry and analysis. SPSS-X for the PC

Amount Requested $\$ 300,00$

\section{PERSONNEL}

Research Assistant (TBA)

Research Assistant is needed to write codebook, code and enter data, and conduct final library search.

$\$ 7 /$ hr. X 5 days/wk. X 4wks./mo. X 6 mo $=\$$ 840.00. Amount Requested: $\$ 840.00$

\section{OTHER COSTS}

Photocopying

A two page questionnaire and cover letter. 3 pages X 5,666 participants (DU printing \& graphics) $=\$ 92.98 \times 3$

Amount Requested: $\$ 300,00$

\section{POSTAQE COST}

Bulk mailings of initial questionnaire to 5,666 participants@\$.24=\$1,359.84 and purchase of Duquesne University returned postage paid envelopes (\$115.00). Second mailing to non-respondents approximately $\$ 150.00$

Amount Requested: $\$ 1600,00$

\section{MAILINO LIST AND LABEL PURCHASE}

Approximately 17,000 names + mailing labels (a) $\$ .55 / 1,000$

Amount Requested: $\$ 1000.00$

\section{BILLBOARD ADVERTISING}

Purchase of two small billboards for a period of one week in each targeted community prior to mailing the questionnaire (per quote: one week billboard ads), The Outdoor Weekly.

Amount Requested: $\$ 700.00$

\section{MISCELLANEOUS}

Computer paper, ink cartridge, disc, white Duquesne University envelopes, basic office supplies. Amount Requested: \$150.00

TOTAL \$ 4890.00 


\section{REFERENCES}

Brookoff D., Kellermann, A.L., Hackman, B.B., Somes, G. Dobyns, P. (1994). Do blacks get bystander cardiopulmonary resuscitation as often as whites? Annals of Emerqency Medicine, 24 (6). 1147-1150.

Cowie, M.R., Fahrenbuch, C.E., Cobb, L.A.,\& Hallstrom, A.P. (1993). Out-of-hospital cardiac arrest: Racial differences in outcome in seattle. American Journal of Public Health, 83 (7), 955-959. Cummins, R.O., Eisenberg, M.S., Hallstrom, A.P., \& Litwin, M.S. (1985). Survival of out-of-hospital cardiac arrest with early initiation cardiopulmonary resuscitation. American Journal of Emerqency Medicine, 3 (2), 114-119.

Cummins, R.O., Ornato,J.P., Theis, W.H.,\& Pepe, P.E. (1991). Improving survival from sudden cardiac arrest: The "chain of survival" concept. American Heart Association Medical Statement 83 (5), 1832 1847.

Cummins, T. (1993). Ethical issues in adult resuscitation. Annals of Emerqency Medicine, 22,(2), 35-40

Emergency Cardiac Care Committee; American Heart Association. (1992). Guidelines for cardiopulmonary resuscitation and emergency cardiac care. JAMA, 268 (16), 21722183.

Guzy, P.M., Pearce, M.L.,\& Greenfield, S. (1983). The survival benefit of bystander cardiopulmonary resuscitation in -paramedic served metropolitan area. American Journal of Public Health 73 (2), 766769.

Hanks, S. (1990). The impact of a supplemental bystander educational unit on the emergency helping behavior of college students. Dissertation Abstracts. Brigham Young University.

Jones, P., \& Mitchell, J. (1993). The Black Health Library Guide to Heart Disease and Hypertension. New York: Henry Holt and Company.

Pepe, P. (1990). Emergency medical services personnel and ground transport vehicles. Problems in Critical Care, 4, 470476.

U.S. Department of Health and Human Services, Public health Service. (1991). Healthy people 2000 (DHHS Publication No. (PHS) 91-50213). Washington, D.C.: U.S. Government Printing Office.

Weaver, Fahrenbuch, C., \& Johnson, D. (1990). Effect of epinephrine and lidocaine therapy on outcome after cardiac arrest due to ventricular fibrillation. Circulation 82, 2027-2034.

\section{MEMO}

To: Jennifer and Paige

From: Donna Brugos

Date: November 5, 1998

Subject: CPR Data

CPR DATA

The data was analyzed by the following:

Freq - Whole house

Freq - by African-American and Caucasian

Chi-square - by African-American and

Caucasian

Because $94.5 \%$ of the responses were either African-Arnerican or Caucasian I did a frequency of the two groups so a comparison could be done between the two groups. The format we usually use is to create a table with the questions in one column, and the responses in two other columns:

Questions Whole House African-American Caucasian

What is your age?

Etc.

The study was intended to develop an intervention that will increase CPR participation by minority individuals. The African-American group was the largest minority in the studv and this group was analyzed individually with some of the results:

- 50\% were 40 years old and above

$-67 \%$ were female

- $63 \%$ had some college or were college graduates

- $42 \%$ had some health care training while $58 \%$ did not

- 54\% had been trained to do CPR.

- 38\% had their last CPR class 5 years ago or more

- 29\% did not feel comfortable with their CPR skills, 54\% felt somewhat comfortable and $18 \%$ felt very cornfortable. 
- 13\% had used CPR while 67\% had not ever used CPR

- Of the ones not knowing CPR, 35\% said it was because of cost, $22 \%$ said it was because they were two busy, and 14\% said they were too old.

- Of the ones not knowing CPR, 92\% said they would like to learn.

- The place tl-ey were like to learn would be the Local school or university (47\%) Or the Community Center (30\%)

If you have hours IcR you'll want to review all of the data elements and write up the results and give them to Kathy Winters.

If you have any questions, call me at (412)3595024

\section{COULD YOU SAVE A LIVE?}

Please answer the following questions describing yourself. (Use a check mark)

1. What is your age?

$$
\begin{array}{ll}
13-19 & 40-49 \\
20-29 & 50-59 \\
30-39 & 60 \text { and above }
\end{array}
$$

\section{Are you}

Male Female

\section{What is your ethmic background?}

African-American

Caucasian (White)

Asian-American

Hispanic-American

Native American

Other, Specify

\section{Highest level of education \\ completed? \\ Grade School \\ HIgh School \\ GED}

Technical School

Some College

College

Never Attended School
5. Have you had any health care training? Yes No

If yes, check level below:

Medical Doctor or Dentist

Nurse

Nurse Aide

Paramedic or EMT

Other, specify

6. What would you do first for someone who passes out or collapses?

Yell for help

Check to see if they were breathing

Call 911

Check to see if they will react

Check their pulse

Ignore them

Administer CPR

Other, Specify

7. Have you ever been trained to do CPR?

Yes No: If YES, continue

If no, go to question \#12

\section{Where did you learn CPR?}

Red Cross

Work

Community

Church

Other, please specify

9. When was the last time you had a class in CPR?

Within the last 2 years

3-4 years ago

5 years ago or more

10. How comfortable are you in your CPR skills?

Not comfortable at all

Somewhatcomfortable

Very comfortable

If not comfortable, why?

Turn Over To Complete The Questionnaire 
11. Have you ever used CPR?

Yes No

12. If you know CPR or learned CPR, would you do CPR on the following people?

$\begin{array}{llll}\text { Family } & \text { Yes } & \text { No } & \text { If no, why not } \\ \text { Friend } & \text { Yes } & \text { No } & \text { If no, why not } \\ \text { Co-worker } & \text { Yes } & \text { No } & \text { If no, why not } \\ \text { Neighbor } & \text { Yes } & \text { No } & \text { If no, why not } \\ \text { Stranger } & \text { Yes } & \text { No } & \text { If no, why not } \\ \text { Another Race } & \text { Yes } & \text { No } & \text { If no, why not } \\ \text { Anyone } & \text { Yes } & \text { No } & \text { If no, why not } \\ \text { No one } & \text { Yes } & \text { No } & \text { If no, why not }\end{array}$

13. Are there any reasons that you would NOT perform CPR on a person?

Yes If yes, what are the reasons?

No

14. Would vou Derform CPR if vou had Drotection for vour mouth?

Yes No

If you know CPR, stop here. If not, please answer questions 15 and 16

15. If you do not know CPR, what is your major reason for not taking a CPR course?

Cost

Not Interested

Afraid I cannot learn or do it right

Too busy

Too old

Disabled

Fear of AIDS

Fear of Diseases other than AIDS

Do not want to do mouth to mouth breathing

Too nervous

Too hard to learn

Do not know

Not offered in my area

Fear of being sued/Lawsuit

Other, specify
16. If you do not know CPR, would you like to learn?

Yes No

If yes, where would you like to have a class?

Local School or University

Community Center

Church

Other, specify

\section{BYSTANDER CPR IN TWO PITTSBURGH COMMUNITIES \\ RCP REALIZADA POR TESTIGOS EN DOS COMUNIDADES DE PITTSBURGH}

\section{ABSTRACT}

$1 \begin{aligned} & \text { pesar de la reciente disminución de la mor- } \\ & \text { talidad, la enfermedad cardiaca coronaria } \\ & \text { continúa siendo la principal causa de }\end{aligned}$ muerte en EEW. La mayoría de estas muertes ocurren súbitamente y fuera del hospital. Hay evidencias de que la reanimación cardiopulmonar ( $\mathrm{RCP}$ ) llevada a cabo por un testigo en la escena del suceso, duplica la posibilidad de supervivencia de la víctima.

Es un hecho que el índice de mortalidad por enfermedad coronaria es más alto entre la raza negra que en la blanca; sin embargo los individuos de raza negra tienen menos posibilidades de recibir RCP por parte de un testigo. No hay evidencia investigadora sobre el porqué de la existencia de este problema (Cowie et al., 1993). Este estudio propone mejorar y probar un cuestionario que identificara el número de personas capacitadas para llevar a cabo una RCP, su predisposición, y las barreras potenciales para ello. Éste sera luego aplicado a una muestra aleatoria de adultos residentes en dos comunidades de Pittsburgh donde demográficamente se observa una alta proporción de residentes de raza negra.

Basados en los datos, los investigadores buscaran financiación externa para desarrollar una intervencion cultural que proporcionara formación en RCP y eliminara barreras a la predisposición a actuar en miembros de ambas comunidades. 


\section{A. OBJETIVOS:}

El objetivo global de este estudio es proporcionar a los investigadores datos de base sobre los cuales desarrollar una intervención que promueva la participación de individuos pertenecientes a minorías en la RCP. La meta específica a largo plazo del estudio es aumentar el índice de supervivencia de afroamericanos víctimas de un ataque cardiaco.

Los objetivos de este estudio son: (1) mejorar y probar un instrumento que identifique posibles reanimadores-testigo (individuos que han recibido, formación en RCP); y (2) determinar hasta qué punto la poblacion adulta residente en las dos areas seleccionadas, con una alta densidad de afroamericanos, está preparada y predispuesta para proporcionar RCP.

Las cuestiones a investigar son:

- ¿Cuáles son las características demográficas de la muestra?

- ¿Qué proporción de la población diana está preparada y predispuesta para llevar a cabo RCP?

- ¿Qué barreras se identifican como limitantes de la participación en la RCP?

\section{B. JUSTIFICACIÓN:}

La investigación sobre enfermedades cardiovasculares en minorías es susceptible de financiación por parte de los Institutos de Salud Nacionales (NIH) ya que constituye una de las áreas de competencia identificadas en la investigacion en enfermería. Sin embargo, con el objeto de ser competitivos a la hora de obtener financiación es imprescindible obtener datos de base a través de estudios piloto y preliminares. Este estudio, que rellena lagunas en la bibliografía sobre RCP en poblaciones minoritarias, contribuiría a disminuir la mortalidad entre ciudadanos afroamericanos con gran riesgo de muerte súbita de etiología cardiaca.

Las enfermedades cardiovasculares constituyen la causa de casi un millón de muertes anuales en EEW, de las que aproximadamente 500.000 son a consecuencia de enfermedad coronaria (Guía para la Reanimación Cardiopulmonar y Cuidados de Emergencia, JAMA 1992). Los índices de mortalidad por enfermedad coronaria son más altos entre hombres que entre mujeres y en negros más que en blancos (Healthy People 2000, 1991).
Más de la mitad de las muertes por ataques cardiacos ocurre durante las primeras horas tras la aparición de los síntomas y antes de llegar al hospital (Jones y Mitchell, 1993). La actuación inmediata a la primera evidencia de ataque cardiaco es crítica a la hora de salvar tejido cardiaco reduciendo la incidencia de fibrilación ventricular a causa de la isquemia y por tanto cara a reducir la morbilidad y mortalidad por enfermedad cardiovascular (Healthy people 2000).

La Asociación Americana del Corazón (AHA) ha identificado eslabones significativos en la cadena de supervivencia que debe iniciarse en las víctimas. El pronto inicio de la RCP es uno de los eslabones clave en la supervivencia. Sin embargo, las víctimas de ataque al corazón de raza negra reciben fuera del hospital RCP de testigos menos frecuentemente que las de raza blanca, de ahí la necesidad de programas de formación para mejorar los indices en grupos de alto riesgo (Brookoff et al., 1994). Cowie et al. (1993) describieron una diferencia significativa en la realización de la reanimación entre negros y blancos ( $17,1 \%$ vs. $40,7 \%)$.

A pesar de los esfuerzos, la repercusión a nivel nacional de la formación en RCP a los ciudadanos se ha visto limitada por varios factores. Es importante determinar el número de personas que han recibido formación en $\mathrm{RCP}$ e investigar barreras que influyan en la provisión de esta RCP a determinadas víctimas, especialmente en poblaciones minoritarias.

\section{PERSPECTIVA HIISTÓRICA:}

1. Introducción - La enfermedad coronaria continúa siendo la principal causa de muerte en EEW. Este hecho ha propiciado varias investigaciones sobre RCP iniciada por un testigo.

Las autoridades de Hill District y East Liberty se pusieron en contacto con la Escuela de Enfermería de la Universidad Duquesne y solicitaron la organización de actividades formativas para diversos grupos. Éstas se llevaron a cabo y se formó subsiguientemente un equipo de investigacion financiado por la Escuela de Enfermería con el fin de comenzar una investigación preliminar sobre la necesidad de entrenamiento en RCP en la comunidad. Ahora se están solicitando más fondos para continuar este proyecto. 
2. Revisión bibliográfica - La revisión bibliográfica ha revelado la necesidad de educar sobre RCP en la comunidad. El objetivo del entrenamiento en RCP/SVB (Soporte Vital Básico) es aumentar la tasa de supervivencia y disminuir la de complicaciones subsecuentes al ataque cardiaco. El tratamiento eficaz empieza en la comunidad con prevención y educación. Proporcionada esta educación, los individuos pueden potencialmente identificar situaciones que requieran una rápida intervención.

Casi toda la literatura e investigaciones acreditan a la RCP realizada por un testigo como de máxima eficacia si se inicia inmediatamente. Para la mayoría de estudios clínicos, la RCP llevada a cabo por un testigo tiene un efecto positivo significativo en la supervivencia (Cummins 1993).

Cummins et al. (1985) en un estudio $(n=1297)$ sobre ataques por enfermedad cardiaca presenciados fuera del hospital demostraron una mayor tasa de supervivencia cuando la RCP la inició un testigo en los cuatro primeros minutos. Guzy et el. (1983) concluyeron que la RCP iniciada antes de la llegada del personal sanitario cuatriplicó las posibilidades de supervivencia. Los datos corroboran la eficacia de La RCP llevada a cabo por un testigo.

Weaver, Fahrenbruch \& Johnson (1993) estudiaron la relación entre la RCP inmediata y la desfibrilación rápida. En un análisis de regresión logistica de la supervivencia en 244 ataques presenciados, los autores hallaron que el retraso en el inicio de la RCP y en la desfibrilación eran predictores de mortalidad. En los casos observados, la tasa de supervivencia descendía casi un tres por ciento por cada minuto de demora en la iniciación de la RCP y continuaba disminuyendo un cuatro por ciento cada minuto tras el comienzo de la RCP hasta el primer choque desfibrilador. Cuando la RCP se empezó dentro de los tres primeros minutos y el choque poco después, 23 de 33 pacientes $(70 \%)$ sobrevivieron.

Cummins y Pepe realizaron otros dos estudios que apoyan que el inicio temprano de la RCP por un testigo conduce a una mayor supervivencia. El estudio llevado a cabo por Cummins (1993) reveló que la RCP realizada por un testigo produjo una supervivencia del $27 \%$, mientras que si la se demoraba hasta la llegada de los servicios de urgencias era sólo del 13\%. El segundo estudio de Pepe (1990) mostró una diferencia de un 40\% frente a un 19\%.

Según Brookoff et al. (1994), los ataques cardiacos fuera del hospital constituyen la causa de más de 250.000 muertes en EEW al ano. Hay evidencias de que la RCP realizada por un testigo duplica la supervivencia. Los investigadores, sin embargo, hallaron que las víctimas adultas de raza negra tenían sólo la mitad de probabilidades de ser atendidos que las de raza blanca $(9,8 \%$ vs. $21,4 \%)$. Este resultado se basó en 1068 casos consecutivos. Las causas no fueron esclarecidas.

Cowie et al. (1993) comprobaron que las poblaciones minoritarias tienen menos conocimientos relativos a la RCP. Su estudio también reveló que las víctimas de raza negra tenían menos posibilidades de ser auxiliados por un testigo (p.959).

Hanks (1990) llevó a cabo un estudio que revelo que un transeúnte está mas predispuesto a ayudar si se percibe a sí mismo competente y si es de las mismas características sociales y psicológicas que la víctima.

En resumen, la revisión de la literatura identifica claramente dos elementos clave en relación a la supervivencia de las víctimas: (1) la RCP iniciada por un testigo mejora la tasa de supervivencia; y (2) existen diferencias entre la supervivencia de adultos negros y blancos.

La revision de la literatura y la implicacion de la Escuela de Enfermería de la Universidad de Duquesne en comunidades desfavorecidas ha establecido el campo de trabajo para este proyecto. Los investigadores visualizan el estudio en dos fases: (1) prueba piloto de un cuestionario que sirva para identificar qué proporción de la población en las dos comunidades está entrenada como potencial auxiliador, quíenes son y su predisposición; y (2) encuesta por correo de adultos residentes en ambas comunidades.

3. Experiencia de los investigadores - El compromiso de la Escuela de Enfermería de la Universidad de Duquesne hacia áreas desfavorecidas parte de la misión misma de la Universidad. La Escuela de Enfermería y los estudiantes han estado activamente implicados en Hill District y East Liberty durante los últimos tres años: clínicas ges- 
tionadas por enfermeras, ferias de la salud, y clases de RCP. La investigadora principal y sus estudiantes han realizado valoraciones de ambas comunidades. Los datos de la valoración se obtuvieron a partir de informadores clave. La valoración se centró en la población, el nivel educativo, la religión, la accesibilidad a los servicios de urgencias, y la mortalidad y morbilidad. Cuando se interrogó a estos informadores sobre el entrenamiento en RCP, hicieron hincapié en la necesidad de tal formación.

Los investigadores han estado en contacto con expertos en la provisión de los Servicios de Urgencias Médicas de Pittsburgh, especialmente con el Centro de Medicina de Urgencias. Según el Director, Robert Kennedy, sólo en el 35\% de RCPs participaron ciudadanos testigos. No se dispone de datos a nivel de vecindad. Basándonos en la literatura (Cowie, Fahrenbruch, Cobb \&Hallstrom, 1993), las comunidades desfavorecidas de Pittsburg tendrían menos conocimientos de RCP y las víctimas negras tendrían menos posibilidades de ser auxiliadas por testigos.

La investigadora principal, Dra. Kathleen Winter, es experta en salud comunitaria y educacion para la salud en la comunidad. Hizo el doctorado en educación para la salud en la comunidad y ha supervisado a numerosos estudiantes pre y postgraduados en la realización de estudios comunitarios e implantación de intervenciones de salud. Como enfermera de salud comunitaria y miembro de la Asociación Americana de Salud Pública, la Dra. Winter está decidida a reducir la morbimortalidad en los grupos de riesgo.

Las áreas de experiencia del co-investigador (Carl Ross) son los cuidados de enfermería al paciente crítico y el entrenamiento en RCP. Posee un Máster en Educación en Enfermería con especialidad en cuidados críticos. Ha trabajado en cuidados intensivos durante nueve años y actualmente gestiona una unidad de intensivos. Es instructor de Soporte Vital Cardiaco Básico (BCLS) y esta cualificado en Soporte Vital cardiaco Avanzado (ACLS). Durante los últimos siete años ha ensenado RCP en hospitales, en la comunidad, e internacionalmente en Nicaragua. Ha trabajado en diversas unidades de cuidados intensivos, hospitales, atencion domiciliaria y rehabilitación en la comunidad. En enero de 1995, fue miembro de un equi- po que enseñó cuidados críticos a un grupo de médicos y enfermeros en Nicaragua. Dirige el Comité de Enfermería Internacional de la Escuela de Enfermería. Esta comprometido con la enfermería transcultural local e internacionalmente, y especialmente con el aumento de la supervivencia de los individuos con alto riesgo de muerte por causa cardíaca.

\section{METODOLOGÍA:}

1. Diseño de la investigación - Para esta fase del estudio lo apropiado es la encuesta. Un cuestionario desarrollado por los investigadores en base a la revisión bibliográfica (se adjunta) y enviado por correo servirá para la recopilación de información.

2. Fase primera- Desarrollo del instrumento

1. El cuestionario se revisará por un panel de expertos en medicina y enfermería cardiovascular para la validación de su contenido.

2. Se llevará a cabo un estudio piloto con 10 representantes de una comunidad afroamericana similar a las del estudio por consideraciones de vocabulario, legibilidad, y parcialidad cultural.

3. El cuestionario se modificará en base a las aportaciones de ambos grupos mencionados.

3. Segunda fase: encuesta enviada por correo

1. Se obtendrá la aprobación de IRB . El estudio se calificaría como exento.

2. Se remitirán los cuestionarios a la población adulta de las dos áreas de Pittsburg. Según el censo de 1990, la población adulta de Hill District es 10.513 y de East Liberty 6.543 .

Idealmente los investigadores estudiarían a la totalidad de la población de ambas comunidades; sin embargo, por motivos de accesibilidad y economía, se empleará una muestra al azar. A partir de una lista de residentes se elegirá un nombre de cada tres sucesivamente.

3. Se espera una respuesta del 33\% o más; si no, se llevará a cabo un segundo envío. Otras medidas adicionales con el objeto de aumentar la respuesta serán: a) folletos/posters anunciando el proyecto en lugares clave, como parroquias y asociaciones de vecinos o centros culturales; y b) tablones de anuncios en sitios estratégicos. 
4. Se obtendrán los datos de respuesta a los cuestionarios. Dado que estudio es exploratorio, no se proponen hipótesis específicas a priori. El análisis de los datos se valdrá de la estadística descriptiva (frecuencias) para determinar: a) características demográficas de la muestra; b) experiencia en RCP; y c) barreras percibidas. Se usará la inferencia estadística (t-test) para establecer las diferencias en la predisposición a aprender RCP y las barreras percibidas según características demográficas.

5. Secuencia temporal/Plazos de las actividades. - Una vez garantizadas la aprobación por el IRB y la financiación, las actividades se desarrollarán de acuerdo al siguiente esquema. Debido al trabajo a tiempo total de los investigadores en la universidad, se requiere un plazo de 16 meses para completar el estudio.

Meses 1-5: mejorar y probar el cuestionario. Revisión final.

Meses 6-10: publicidad del proyecto. Recopilación de datos. Segundo envío si es necesario.

Meses 11-13: Creación de base de datos

Meses 14-15: Resumen de los resultados. Manuscrito preliminar.

Mes 16: Envío del informe final. Comienzo de la intervención educativa.

\section{E. RESULTADOS:}

Mediante el estudio los investigadores identificarán las características más importantes de la poblacion diana en las dos comunidades con el objeto de que ello sirva de base para el desarrollo de una intervención cultural válida. La intervención incluirá formación en RCP, identificacion de barreras a la predisposición a realizar RCP, y disminución de la mortalidad y morbilidad en esas áreas.

\section{F. EVALUACIÓN:}

La evaluación del estudio se basará en la consecución de los dos objetivos. Se establece como participación aceptable una respuesta del 33\% a los cuestionarios. El equipo multidisciplinar que en un principio colaboró en la conceptualización del estudio se encargará de la monitorización de los datos.
Este equipo de enfermeras y médicos participaran tanto en la evaluación de los resultados como en la preparación de la propuesta al Instituto Nacional de Salud (NIH). El comité colaborador de las comunidades diana apoyarán la evaluación de los resultados en lo que respecta a aspectos culturales.

\section{G. PLANES FUTUROS:}

1. Posibilidades de financiación - Basándose en los resultados del proyecto, la intención de los investigadores es solicitar financiación externa para: 1) Iniciar una actividad educacional en RCP que tenga en cuenta aspectos culturales e identifique barreras; y 2) extender el uso del cuestionario por toda el área de Pittsburg.

Se espera asimismo que se pueda desarrollar a partir de estos datos una intervención válida culturalmente que sirva de modelo para otros profesionales de la salud dedicados a mejorar la salud de poblaciones minoritarias.

2. Posibilidades de publicación/presentación Como resultado del estudio, se dispondrá de varios manuscritos susceptibles de presentación, tanto sobre el cuestionario probado como sobre los resultados mismos del estudio.

La mejora del cuestionario podría incentivar la creación de una base de datos de referencia para investigadores de otras ciudades.

\section{H. PRESUPUESTO. (resumen) EOUIPAMIENTO:}

Paquete de software

$\$ 300$

\section{PERSONAL:}

Ayudante de investigación $\$ 840$

\section{OTROS COSTES:}

Fotocopias

$\$ 300$

\section{CORREOS:}

Envíos y sobres de respuesta franqueados $\$ 1600$ 


\section{LISTA DE CORREOS Y ETIOUETAS}

$\$ 1000$

ANUNCIOS EN TABLONES Y PERIÓDICOS

$\$ 700$

\section{MISCELANEA:}

Papel de ordenador, tinta, material de oficina $\$ 150$

TOTAL $\$ 4890$

\section{¿PODRÍA VD. SALVAR UNA VIDA?}

Por favor responda a las siguientes preguntas sobre Vd. mismo (use una $\mathrm{X}$ u otro signo para marcar)

\section{Edad:}

13-19 40-49

20-29 50-59

30-39 60 o mas

\section{Sexo:}

hombre/mujer

\section{Grupo étnico:}

Afroamericano

Caucasiano (blanco)

Asiático-americano

Hispanoamericano

Americano nativo

Otro, especificar:

\section{Educación finalizada:}

Universidad

Bachillerato

Formación profesional

Alguna Academia

Escuela básica

No fui a la escuela

\section{5. ¿Ha tenido alguna formación en cuidados} de la salud?

Sí

No
Si su respuesta es afirmativa, señale aquí:

Médico o dentista

Enfermero

Auxiliar de enfermería

Camillero u otro del SAMU

Otros; especificar

6. ¿Qué haría primero si alguien se desmaya o sufre un ataque?

Gritar para pedir ayuda

Comprobar si respira

Llamar al 112

Comprobar si reacciona

Comprobarle el pulso

Ignorarle

Realizar RCP

Otros, especificar

\section{7. ¿Ha sido entrenado alguna vez en RCP?}

Sí

No. Si la respuesta es afirmativa, continuar.

Si no, pasar a la pregunta $n^{\circ} 12$

\section{8. ¿Dónde aprendió la RCP?}

Cruz Roja Trabajo

Asociación de vecinos o similar

Parroquia

Otros, especificar

9. ¿Cuándo recibió por última vez una clase sobre RCP?

Durante los últimos 2 años

Hace 3-4 años

Hace 5 años o más

10. ¿Cómo de competente (cómodo) se siente respecto a su destreza en RCP?

Nada competente

Algo competente

Muy competente. Si no se siente competente, ¿por qué?

11. ¿Alguna vez a realizado RCP? Sí

No 
12. Si ha aprendido o sabe realizar RCP, ¿la aplicaría a las siguientes personas?

Familia

Sí No Si no, ¿por qué?

Amigo

Sí No Si no, ¿por qué?

Compañero

Sí No Si no, ¿por qué?

Vecino

Sí No Si no, ¿por qué?

Desconocido

Sí No Si no, ¿por qué?

Otra raza

Sí No Si no, ¿por qué?

Cualquiera

Sí No Si no, ¿por qué?

Nadie

Sí No Si no, ¿por qué?

13. ¿Existe alguna razon por la que NO realizaría RCP a una persona?

Sí ¿Qué razones? No

14. ¿Realizaría RCP si tuviera protección para la boca?

Sí No

SI CONOCE LA RCP, NO CONTINÚE. SI NO, POR FAVOR SIGA CON LAS PREGUNTAS 15 Y 16
15. Si no conoce la RCP, ¿por qué no ha hecho un curso?

Por el coste

No me interesa

Temo no ser capaz de aprender o de hacerlo bien

Estoy demasiado ocupado

Soy demasiado mayor

Soy discapacitado

Tengo miedo del SIDA

Tengo miedo a otras enfermedades

No quiero hacer el boca a boca

Soy demasiado nervioso

Es demasiado complicado de aprender

No lo sé

No lo ofrecen en mi barrio

Temo ser denunciado/querellado

Otros, especificar

16. Si no sabe RCP, ¿lle gustaría aprender? Sí No

Si la respuesta es afirmativa, ¿dónde le gustaría que fuera la clase?

Escuela local o universidad

Centro comunitario

Parroquia

Otros, especificar 